(26) The limits of the second integral of Appendix II should be moved to the right. (27) Reference 1 should be: Tschoegl, $N$. $W .$, Rheol. Acta 10, 595 (1971).

(28) Reference 8 should be Okano, $M$., Busseiron Kenkyu 3, 493 (1958).

(29) Reference 12 is incomplete. It should be: Ferry, J. D. and $M$. L. Williams, J. Colloid Sci. 7, 347 (1952).

(30) The second and third sentences of the second new paragraph in the left hand column of page 592 should read: Approximations of any order higher than the first, based on the Stieltjes transform inversion, were given by Okano (8) and those of even order by Fujita (9) but without the appropriate shift in the time scale of the spectrum where applicable. In addition, Fujita's approximations were not normalized. ed.

(31) Fig. 2 and Fig. 3 should be interchang-

(32) In the caption to Fig. $7 \log H^{\prime}(\sqrt{3} \tau)$ should read $\log H_{3}^{\prime}(\sqrt{3} x)$.

(33) The 3rd line of the 3rd paragraph in the left column of p. 588 should read $I_{3 R R}^{\prime}(\omega \tau)$ instead of $I_{2 \mathrm{RR}}^{\prime}(\omega \tau)$.

(34) Line 2 in the right column on p. 588 should read $H^{\prime}{ }_{3}(\sqrt{3} \tau)$ instead of $H_{3 \mathrm{R}}^{\prime}(\sqrt{3} \tau)$.

\title{
Berichtigung zu Statik in rechtwinklig-krummlinigen Koordinaten nebst Anwendung auf Fragen der rheostatischen Schmierung
}

Von $M$. Biermann (Berlin)

in Rheologica Acta Band 11, Seite 341-350 (1972)

Auf Seite $342 \mathrm{muß}$ das erste Glied der zweiten Zeile von Gleichung $[6] \frac{\partial T\langle i j\rangle}{h_{j} \partial \xi j}$ statt $\frac{\partial T\langle i j\rangle}{h_{j} \partial \xi i}$ lauten.

Fußnote ${ }^{11}$ ) gehört nicht auf Seite 349 , sondern ausschließlich auf Seite 350 zu Literaturhinweis (8). Am Schluß dieser Fußnote ist ,fehlerhaft." zu ergänzen.

\section{MITTEILUNGEN}

\section{The British Society of Rheology}

The 1973 Autumn Conference of the Society will be held at the University of East Anglia, Norwich, from September 18-21. The theme of the conference will be "Modern Developments in Rheology"; the scope of the meeting will be quite general, but it is hoped that, within it, specific sessions on "Elongational Flow" and "Multiphase Systems" will be arranged.

Offers of papers for this Conference are invited. Prospective authors are asked to give notice of intent to submit a paper at the earliest possible date. More definite information, in the form of a title and an abstract, should be submitted no later than April 30th 1973. Prospective authors are asked to write to: Dr. K. M. Beazley, 44 Brockstone Road, Boscoppa, St. Austell, Cornwall, (U. K.)

Für die Schriftleitung verantwortlich: Dr. W. Meskat, 5090 Leverkusen

Anzeigenverwaltung: Dr. Karl Niedermeyer Nachf., 6000 Frankfurt/Main 90, Georg-Speyer-Straße 76

Dr. Dietrich Steinkopff Verlag, 6100 Darmstadt, Saalbaustraße 12

Herstellung: Universitätsdruckerei Mainz GmbH, 6500 Mainz 